\title{
Corrigendum
}

\section{Drivers and Blockers: Embedding Education for Sustainability (EfS) in Primary Teacher Education}

\author{
Sue Wilson
}

doi:http://dx.doi.org/10.1017/aee.2012.5, Published by Cambridge University Press 2012.

The author Wilson would like to correct their corresponding email address to the below: Sue.Wilson@acu.edu.au

\section{Reference}

Sue, Wilson (2012). Drivers and Blockers: Embedding Education for Sustainability (EfS) in Primary Teacher Education. Australian Journal of Environmental Education, 28, pp 42-56. doi:10.1017/aee.2012.5. 